\title{
Trust as a mediating effect of social media marketing, experience, destination image on revisit intention in the COVID-19 era
}

\author{
Pande Gde Bagus Naya Primananda ${ }^{a^{*}}$, Ni Nyoman Kerti Yasa ${ }^{a}$, I Putu Gde Sukaatmadja ${ }^{a}$ and Putu \\ Yudi Setiawan ${ }^{\text {a }}$
}

\begin{tabular}{l}
$\frac{{ }^{a} \text { Economics and Business Faculty, Ud }}{\text { C H R O N I C L E }}$ \\
\hline Article history: \\
Received: June 22, 2021 \\
Received in revised format: \\
September 21, 2021 \\
Accepted: December 7, 2021 \\
Available online: December 7, \\
2021 \\
\hline Keywords: \\
Social media marketing \\
Experience \\
Destination image \\
Trust \\
Revisit intention \\
Covid-19
\end{tabular}

na University, Bali - Indonesia

\section{A B S T R A C T}

\begin{abstract}
The Covid-19 pandemic has a huge impact on the economy, which causes a substantial decline in the tourism sector. On the other hand, the detrimental impact of proactive measures taken to control the Covid-19 pandemic has had a negative impact on all industries around the world including tourism. Therefore, the purpose of this study is to learn on how trust can have an impact on the intention to revisit during the Covid-19 pandemic. The study uses 125 respondents from domestic tourists who visited Bali during the Covid-19 pandemic and had come to Bali before the Covid-19 pandemic. The study uses PLS as a statistical analysis. Our survey shows that while destination image influences intention, it does not have any meaningful effect on trust. Also, trust influences on intention, and experience influences positively on both trust and intention. In our survey, while social media marketing influences significantly on intention, it has no meaningful effect on trust.
\end{abstract}

(C) 2022 by the authors; licensee Growing Science, Canada.

\section{Introduction}

The tourism industry, including a business that continues to grow until now, even has very good prospects and has extensive links with several other industries so that it is able to encourage economic growth. Tourism contributes more than 10 percent of the world's gross domestic product (GDP). The contribution of the tourism sector is projected to grow 50 percent in the next 10 years in line with the increase in the middle class group in the world, especially in the Asian region. The development of technology today is very helpful in marketing tourism. The technology in question is the development of information communication technology and transportation technology. Information technology is developing very rapidly with the emergence of the internet in it. The internet can provide information to its users by displaying images, videos and sounds (Amaro et al., 2016). The development of transportation can be seen by the number of airlines that set fares that can still be reached by tourists besides tourists can come by sea and also by land. At this time the world is experiencing a COVID-19 virus pandemic which has a significant impact on the global economy, politics and socio-culture (Sigala, 2020). Communication strategies and measures such as social distancing, travel and mobility restrictions, overcrowding and selfquarantine have stopped domestic and international tourism travel, segments of some air transportation, cruise ships, public and private transportation, accommodations such as hotels, restaurants, several gatherings and events. sports festival. According to data from the UNWTO, international arrivals fell 81 percent in July and 79 percent in August, the two busiest months and the peak of summer in the northern hemisphere. As a result of this decline, the loss of export revenue of USD 730 billion from international tourism is more than eight times the loss experienced in the 2009 global economic and financial crisis (UNWTO, 2020).

* Corresponding author.

E-mail address: pandemagina@gmail.com (P. G. B. N. Primananda)

(C) 2022 by the authors; licensee Growing Science, Canada. doi: $10.5267 /$ j.ijdns.2021.12.002 
Travel restrictions are seen as a major barrier blocking the path of international tourism's recovery, along with slow containment of the virus and low consumer confidence. The lack of a coordinated response between countries to ensure harmonized protocols and coordinated restrictions, as well as the deteriorating economic environment were also identified by experts as important obstacles to recovery. (UNWTO, 2020). Asia and the Pacific, the first region to be affected by the pandemic and the region with the highest levels of travel restrictions to date, saw an 82 percent drop in arrivals in the first ten months of 2020. The Middle East saw a 73 percent drop, while Africa saw a 69 percent drop. International arrivals in Europe and America decreased 68 percent.

In the following sections we will provide a brief and general discussion of the effects of social media marketing, experience, destination image, trust and return intention. Furthermore, the method used to evaluate the proposed model and conclusions as well as the theoretical implications and practical implications which contain how destinations are dealing with Covid-19 at this time.

\section{Background of the research}

On the other hand, the Indonesian government prohibits the entry of foreign nationals from all countries starting from January 1, 2021 to January 14, 2021, on the grounds that there is a new virus covid 19 which has a faster spread. (Sandy, 2020) Meanwhile, in Bali Tourism due to the impact of the pandemic, Bali, which 54 percent of its GRDP contributed from the tourism sector, was recorded in the third quarter of 2020, Bali's economic growth was at minus 12.28 percent as a result, Bali lost tourism foreign exchange generated on average. reached Rp 9.7 trillion per month before the pandemic. In 2019 foreign tourist visits to Bali amounted to 6.2 million tourists who contributed about 28.9 percent of the national foreign exchange of IDR 270 trillion. The Covid-19 pandemic has an impact on the economy especially related to the tourism sector causing stagnation, unpaid vacations and downsizing of structures in companies, on the other hand Misinformation can make the pandemic worse by inciting people to fight against each other. which can cause various social problems such as violence and crime and can hinder efforts to keep the virus under control (Yeh, 2020). Therefore, it is important to have a unified voice to represent the government as described by research by Jiang and Ritchie (2017), namely the importance of building trust with open communication because it can result in more effective collaborative efforts in post-crisis recovery. On the other hand, the detrimental impact of proactive actions taken to control the Covid-19 pandemic has had a negative impact on all industries around the world including tourism (Crossley, 2020). Therefore, the solution is to promote domestic tourism, of course, with conditions by maintaining health protocols (Hasan and Soliman, 2020). The same thing was expressed by Helble and Fink (2020), namely with the existence of international travel borders and the fear of being infected with the coronavirus, domestic travel offers a better opportunity to start early because domestic tourism is relatively easier to promote, it becomes a shortterm destination in various regions. because the situation is unprecedented and the coming months will show how successfully the government will use domestic tourism to close the gap left in the absence of international tourists. Many countries consider domestic travel as a long-term recovery as an example of the past spread of the SARS and H1N1 viruses which caused a decline in international tourists (Hasan and Soliman, 2020). Based on data from the Denpasar Ngurah Rai Airport Command Post, the average daily growth of passengers during the Christmas and New Year holidays was 14 percent and data from 18 December to 26 December 2020 passengers who came to Bali as many as 62,093 people who visited Bali. (Sandy, 2020).

The intention to revisit is very important in the development of the tourism industry because this behavior always prioritizes the goods and services of the companies that become customers. Tourists who have this behavior tend to be positive and consume lower marketing costs than new tourists (Zhang, 2014). The intention to revisit is a form of customer trust in a tourist destination. The research that discusses trust with revisit intentions was carried out by Matute et al. (2016) found that trust has a significant effect on repurchase intention. The dire impact of Covid-19 requires trust which is the antecedent of intention to revisit. This trust can be in the form of trust in local communities, trust in private institutions and the implementation of health protocols carried out by the government. In the following section is the development of the conceptual framework and research hypotheses.

\section{Conceptual framework}

\subsection{Social media marketing and revisit intentions}

Tourists use social media to find and share information about destinations, namely before carrying out tourism activities, during tourism activities and after conducting tourism activities (Amaro et al., 2016). Therefore, social media is an important source of information in the world of tourism which can be said to change the way tourists search, find, read and process the information they get about tourist destinations (Kim et al., 2017). Previous research stated that online WOM had a significant effect on the intention to revisit. Research conducted by Hajili et al. (2016) found that searching for information through the internet has a significant effect on repurchase intentions. Hajli et al. (2016) explained that the more customers search for information on the internet, the more they tend to buy. Based on the description 3.1, the hypothesis of this research is as follows,

\section{$\mathbf{H}_{1}$ : Social media marketing has a positive and significant effect on revisit intentions.}




\subsection{Experience and intention to revisit}

Tourists usually always want something new in their life and go somewhere they have never been before. There are many motivations for doing a trip, including taking time to relax with family and going to places that have not been visited by friends. Different motivations are found by other foreign tourists, their motivations include feeling the lifestyle, avoiding the demands of work, reminiscing and taking on new challenges but there is no guarantee for them to return because their motivation has been fulfilled. The results of research conducted by Ali et al. (2015) mentions that tourists need peace of mind, serving tourists at their leisure and getting experiences can make tourists satisfied with a tourist destination so that they can make tourists want to come back. The results of this study found that there was a significant influence between experience and intention to revisit. The same result was found by Coudonaris and Stapit (2017) who found that experience had a significant effect on revisit intention

\section{$\mathbf{H}_{2}$ : Experience has a positive and significant effect on the intention to revisit.}

\subsection{Destination image and intention to revisit}

Research conducted by Baloglu and Mccleary (1999) explains that the image of a destination is formed by two main factors, namely the stimulus factor and the personal factor. The concept of image is generally regarded as an attitude construct consisting of cognitive, affective and global impressions of an object or goal. Cognitive refers to beliefs or knowledge about the destination, affective refers to feelings or interests and the overall image depends on the cognitive and effectiveness of the tourist destination. Research conducted by Stylos et al. (2016) found that cognitive image had an insignificant effect on repetitive behavior while another study conducted by Deng (2014) and Kim (2017) found that there was a significant effect between destination image on revisit intention while Foroudi et al. (2018) also found that the image of the destination is one of the factors for tourists wanting to return to visit a tourist destination.

\section{H3: Destination image has a positive and significant effect on revisit intentions.}

\subsection{Trust and intention to revisit}

Hajli et al. (2016) say that trust plays an important role in trading and can increase intention to buy. The research that examines trust and revisit intention was conducted by Laroche et al. (2013), Kim and Park (2013), Shrivastava (2016), Tatars and Erdogmus (2016) and Lin et al. (2017) who found that trust had a significant effect on revisit intentions. Abubakar and Ilkan (2015) explain that in addition to trust, which plays an important role in increasing visits, e-wom is positive because it can give its own impression of the experiences that have been shared. Based on the description above, the following hypothesis can be formed:

\section{$\mathbf{H}_{4}$ : Trust has a positive and significant effect on the intention to revisit.}

\subsection{Social media marketing and trust}

Social media also creates a sense of discomfort and distrust of its users. Social media users nowadays often do unhealthy things such as speaking rudely or spreading fake news. Research conducted by Mkono and Tribe (2016) explains that the types of social media users are trolls, activists, socialites, social critics and information seekers. The study explains that trolls are obnoxious, abusive, insulting and often disconnected users of social media. Users of social media like that will be very threatening and of course the information obtained can be bad, especially during the covid19 pandemic. Research examining the influence between social media marketing and trust was conducted by Hajli et al. (2013), Abubakar and Ilkan (2015), Abubakar et al. (2016) found that social media marketing has a significant effect on trust. Based on the description above, the following hypothesis can be formed:

\section{H5: Social media marketing has a positive and significant effect on trust.}

\subsection{Experience and trust}

Mahika (2011) explains that one of the factors that make tourists visit is the experience factor gained in the past either at that destination or at other destinations. The experiences gained can be positive experiences or negative experiences. Research examining the influence between experience and belief was conducted by Chen et al. (2010), Sahin et al. (2011), Hao et al. (2015), Baser et al. (2015) and Ardyan (2016) found that experience had a significant effect on trust. Huang (2017) also explains that companies that want loyal customers must adopt sensory marketing, namely seeing, feeling, touching and listening so that if customers have had this sensory experience, they can make customers feel love and believe in their products. Based on the description above, the following hypothesis can be made:

\section{H6: Experience has a positive and significant effect on trust.}




\subsection{Destination image and trust}

The image of the destination is widely recognized by the strong in the tourism industry and can be used as a competitive advantage. (Foroudi et al., 2018). Research examining the influence between image and trust was conducted by Alhaddad (2015), Lien et al. (2015) and Song et al. (2019) found that image has a significant effect on trust. Endah et al. (2017) explained that trust is the most important dimension in this study because it can build tourists' emotional bonds with destinations and influence tourist behavioral intentions. Based on the description above, the following hypothesis is formed:

\section{$\mathbf{H}_{7}$ : Destination image has a positive and significant effect on trust.}

\subsection{Trust as mediation}

Trust has been studied from a wide variety of fields including psychology, sociology and economics. The field of psychology explains that trust is focused on personal characteristics. In the field of trust sociology emphasizes institutional trust, while in the field of economics trust is divided into two approaches, namely trust as an expectation to interact and trust related to exposure and acceptance of weaknesses (Kim \& Park, 2013). Trust is a variable that plays an important role as an antecedent of revisiting intentions. During the COVID-19 pandemic, trust is needed from local communities, private institutions and the role of the government in health protocol policies. Chen and Pou's research (2013) explained that trust is the right predictor and makes tourists feel love so that it has an impact on revisit intentions compared to satisfaction. Therefore, the hypotheses of this research are as follows,

\section{$\mathbf{H}_{\mathbf{8}}$ :Trust can mediate the effect of social media marketing on revisit intentions.}

H9:Trust can mediate the effect of experience on revisit intention.

$\mathbf{H}_{10}:$ Trust can mediate the effect of destination image on revisit intentions.

\section{Methodology}

\subsection{Data collection}

The respondents of this study were domestic tourists who had already come to Bali and tourists who came to Bali during the COVID-19 pandemic. The respondents of this study were taken as many as 125 respondents and will be distributed via google form. The respondent's criteria are tourists who have come to Bali during the Covid-19 pandemic and have come to Bali before Covid-19. The tourists in question are domestic tourists.

\subsection{Measurements}

Social media marketing consists of 7 indicators, namely relevance, timeliness, competence, interest, value add and perceived risk. namely (Lee et al., 2002; DeLone \& McLean, 2003; Sano, 2014; Filieri et al., 2015; Kim et al., 2017). Experience consists of 5 indicators, namely positive emotion experience, novelty, perceived local hospitality, social interaction and hedonism. Kim et al. (2012), Kim and Ritchie (2013), Kim (2014), Chandralal and Valenzuela (2015), Tasci and Ko (2015). Destination image consists of 8 indicators, namely natural attraction, historical attraction, entertainment, climate and environment, amenities, sport facilities, accessibility and ancillary service and level of price (Beerli and Martin, 2004; Dortyol et al., 2014; Stylos et al., 2016; Foroudi et al., 2018). Trust consists of 3 indicators, namely trust in local people, trust in private institutions and the prevention of COVID-19 (Roy et al., 2001; Celafato et al., 2015; Wang et al., 2016; Lu et al., 2016; Artigas et al.., 2017). The intention to revisit consists of 3 indicators, namely strong intention, plan to visit and consider as first choice (Souiden et al. 2017; Zhang et al., 2017; Tosun et al., 2015; Hong et al., 2013).

\section{Result and Analysis}

This research was conducted by distributing google forms which were distributed through the WhatsApp application. Based on the results of data collection, it will be explained by Fig. 1.

In the following, to produce an outer loading above 0.70 , it will be eliminated. In addition, elimination will be carried out again if the AVE does not meet the requirements. The following are the results of the reconstructed outer loading which will be explained in Table 1. The outer loading results in Table 1 show that all construct indicators in the model are valid because the loading factor value $>0.70$ and the resulting T-Statistics value $>1.96$. This means that no indicators are deleted or excluded from the model and there is no need for re-calculation, so that all indicators meet convergent validity. 

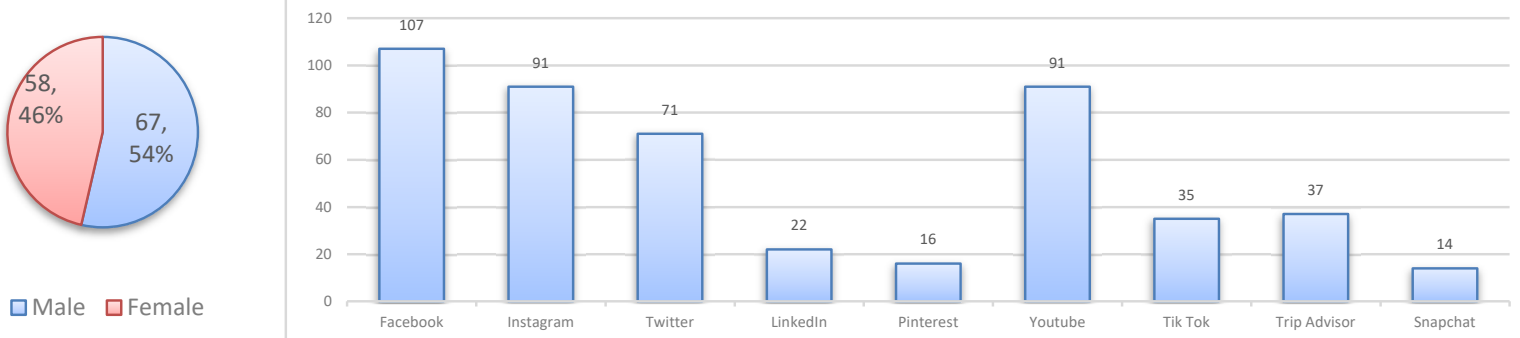

$\square$ Male $\square$ Female

Characteristics of respondents based on their social media sites

Gender
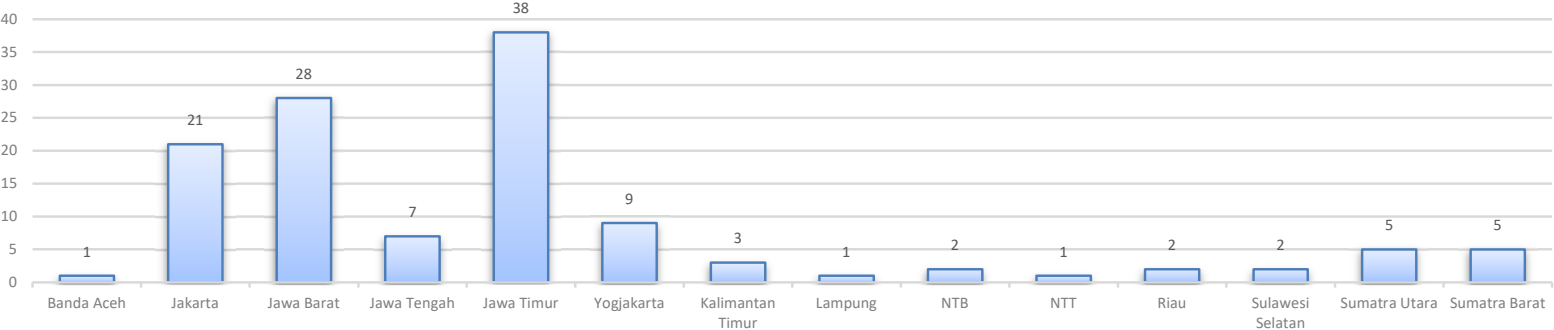

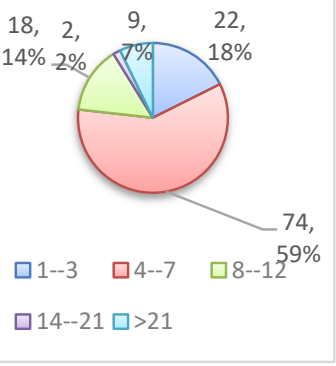

Length of stay (in days)
Characteristics of respondents based on tourist origin

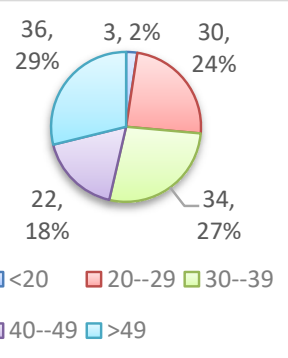

Age

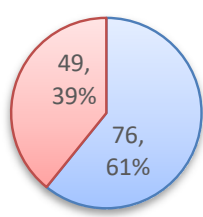

$\square 2020 \quad \square 2021$

Last visit in Bali during

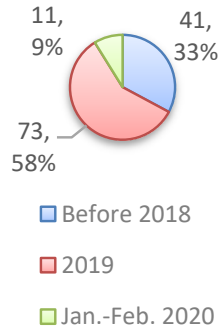

Last visit in Bali before COVID19

Fig. 1. Characteristics of respondents

Table 1

Outer Loading Value after Reconstruction

\begin{tabular}{|c|c|c|c|c|c|}
\hline Indicators & Original Sample & Sample mean & Standard Deviation & Standard error & T Statistics \\
\hline $\mathrm{X}_{1.6 .1}$ & 0.71 & 0.7 & 0.07 & 0.07 & 10.1 \\
\hline $\mathrm{X}_{2.1 .1}$ & 0.89 & 0.89 & 0.02 & 0.02 & 35.5 \\
\hline $\mathrm{X}_{2.3 .1}$ & 0.79 & 0.78 & 0.06 & 0.06 & 12.5 \\
\hline $\mathrm{X}_{3.5 .1}$ & 0.8 & 0.79 & 0.06 & 0.06 & 12.7 \\
\hline $\mathrm{X}_{3.5 .2}$ & 0.82 & 0.81 & 0.05 & 0.05 & 16.4 \\
\hline $\mathrm{X}_{1.2 .1}$ & 0.72 & 0.71 & 0.06 & 0.06 & 10.5 \\
\hline $\mathrm{X}_{1.2 .2}$ & 0.88 & 0.87 & 0.03 & 0.03 & 26.7 \\
\hline $\mathrm{X}_{1.3 .1}$ & 0.89 & 0.89 & 0.02 & 0.02 & 33.2 \\
\hline $\mathrm{X}_{1.3 .2}$ & 0.89 & 0.89 & 0.03 & 0.03 & 29.7 \\
\hline $\mathrm{X}_{1.3 .3}$ & 0.9 & 0.9 & 0.02 & 0.02 & 31.7 \\
\hline $\mathrm{X}_{1.4 .1}$ & 0.89 & 0.89 & 0.02 & 0.02 & 32.6 \\
\hline$X_{1.4 .2}$ & 0.9 & 0.9 & 0.02 & 0.02 & 33.4 \\
\hline $\mathrm{X}_{1.5 .1}$ & 0.86 & 0.86 & 0.03 & 0.03 & 26.7 \\
\hline $\mathrm{X}_{1.5 .2}$ & 0.89 & 0.88 & 0.02 & 0.02 & 33.6 \\
\hline $\mathrm{X}_{1.6 .2}$ & 0.82 & 0.82 & 0.4 & 0.4 & 18.3 \\
\hline $\mathrm{X}_{2.1 .2}$ & 0.87 & 0.87 & 0.02 & 0.02 & 32 \\
\hline$X_{3.2 .3}$ & 0.74 & 0.74 & 0.06 & 0.06 & 11.3 \\
\hline$X_{3.3 .2}$ & 0.73 & 0.73 & 0.08 & 0.08 & 8.8 \\
\hline$X_{3.5 .3}$ & 0.87 & 0.87 & 0.03 & 0.03 & 27.9 \\
\hline $\mathrm{X}_{3.8 .1}$ & 0.72 & 0.72 & 0.06 & 0.06 & 11.7 \\
\hline$Y_{1.3 .1}$ & 0.84 & 0.84 & 0.03 & 0.03 & 22.6 \\
\hline $\mathrm{Y}_{2.1}$ & 0.84 & 0.84 & 0.04 & 0.04 & 17.6 \\
\hline$Y_{1.3 .2}$ & 0.92 & 0.92 & 0.02 & 0.02 & 43.9 \\
\hline$Y_{1.3 .3}$ & 0.93 & 0.93 & 0.02 & 0.02 & 54.1 \\
\hline $\mathrm{Y}_{1.3 .4}$ & 0.91 & 0.91 & 0.02 & 0.02 & 43.3 \\
\hline $\mathrm{Y}_{1.3 .5}$ & 0.91 & 0.91 & 0.02 & 0.02 & 47.8 \\
\hline$Y_{2.2}$ & 0.91 & 0.91 & 0.02 & 0.02 & 43.7 \\
\hline $\mathrm{Y}_{2.3}$ & 0.83 & 0.83 & 0.03 & 0.03 & 24.8 \\
\hline
\end{tabular}


Table 2 shows that the AVE root value of all constructs is between 0.61-0.82 which is greater than the correlation between constructs which is between $0.29-0.59$ and the AVE value of all constructs is $>0.50$, so it meets the valid requirements based on the criteria. discriminant validity.

Table 2

EVA Calculation Results and Correlation Values Between Latent Variables

\begin{tabular}{|c|c|c|c|c|c|c|c|}
\hline Variables & Destination image & Trust & Intention & Social Media Marketing & Experience & AVE & $\operatorname{root} \mathrm{AVE}$ \\
\hline Destination image & 1 & & & & & 0.73 & 0.86 \\
\hline Trust & 0.37 & 1 & & & & 0.73 & 0.86 \\
\hline Intention & 0.59 & 0.5 & 1 & & & 0.61 & 0.79 \\
\hline $\begin{array}{l}\text { Social Media } \\
\text { Marketing }\end{array}$ & 0.29 & 0.23 & 0.46 & 1 & & 0.82 & 0.90 \\
\hline Experience & 0.57 & 0.45 & 0.67 & 0.23 & 1 & 0.75 & 0.86 \\
\hline
\end{tabular}

Table 3 explains that the composite reliability value of all variables shows a value greater than 0.70 so that it meets the reliable requirements based on the composite reliability criteria. Likewise, the Cronbach Alpha value shows that all constructs are higher than 0.70 thus meaning the social media marketing variable, experience, destination image, trust and revisit intention in this study are reliable

Table 3

Calculation Results of Composite Reliability and Cronbach Alpha

\begin{tabular}{|c|c|c|c|c|}
\hline No & Variable & Cronbach Alpha & Composite Reliability & Information \\
\hline 1 & Social media marketing & 0.97 & 0.97 & Reliable \\
\hline 2 & Experience & 0.86 & 0.9 & Reliable \\
\hline 3 & Destination Image & 0.96 & 0.9 & Reliable \\
\hline 4 & Trust & 0.95 & 0.96 & Reliable \\
\hline 5 & Intention to revisit & 0.92 & 0.90 & Reliable \\
\hline
\end{tabular}

In Table 4 the R2 value of trust is 0.22 based on Chin's criteria (Lathan \& Ghozali, 2012:85), then the model includes the model criteria close to moderate, meaning that variations in trust can be explained by variations of social media marketing, experience and destination image by 22 percent, the remaining 78 percent is explained by variations of other variables. While the intention to revisit has an R-square value of 0.59 or includes a model that is close to strong, meaning that variations in social media marketing, experience, destination image and trust can explain the variation of revisit intention, which is 59 percent, the remaining 41 percent is explained by variations of other constructs outside the model.

Table 4

Evaluation of the Inner Structural Model

\begin{tabular}{cc}
\hline Variable & R Square \\
\hline Social Media Marketing (X1) & Experience (X2) \\
Destination Image (X3) & Trust (Y1) \\
Intention (Y2) & 0.226784 \\
\hline
\end{tabular}

The magnitude of the Q-Square value is $1-(1-\mathrm{R} 12)(1-\mathrm{R} 22))=1-(1-0.23)(1-0.60)=1-0.23=0.77$, based on this result, the estimation model results is included in the strong criteria, meaning that 77 percent of the variation of endogenous constructs can be predicted by variations of exogenous constructs. Calculation with GoF shows a value of AR2 * A.Com $=$ $0.81 * 0.726=0.58$ This means that the global model is predictive in the criteria of a good model (large). The path analysis of this research will be explained in Table 5 below

Table 5

Path Analysis and Statistical Testing

\begin{tabular}{|c|c|c|c|c|c|c|}
\hline Variable & Original Sample & Sample mean & Standard Deviation & Standard error & T Statistics & Result \\
\hline Destination image $\rightarrow$ Trust & 0.16 & 0.16 & 0.11 & 0.11 & 1.4 & Not significant \\
\hline Destination image $\rightarrow$ Intention & 0.23 & 0.23 & 0.09 & 0.09 & 2.7 & Significant \\
\hline Trust $\rightarrow$ Intention & 0.18 & 0.18 & 0.09 & 0.09 & 2 & Significant \\
\hline Social media marketing $\rightarrow$ Trust & 0.08 & 0.08 & 0.1 & 0.1 & 0.7 & Not significant \\
\hline $\begin{array}{l}\text { Social media marketing } \rightarrow \text { Inten- } \\
\text { tion }\end{array}$ & 0.2 & 0.2 & 0.07 & 0.07 & 3.2 & Significant \\
\hline Experience $\rightarrow$ Trust & 0.3 & 0.3 & 0.09 & 0.09 & 3.4 & Significant \\
\hline Experience $\rightarrow$ Intention & 0.4 & 0.4 & 0.1 & 0.1 & 3.8 & Significant \\
\hline
\end{tabular}

Source: Appendix (Data processed, 2021)

Based on the path analysis above, H1 - H4 get significant results. These results lead to the meaning that the better the information available on social media can lead to the intention to revisit, experience also has a significant effect on the intention 
to revisit as well as the image of the destination which has a significant effect on the intention to revisit. Social media marketing and destination image have no significant effect on trust. Therefore, $\mathrm{H} 5$ and $\mathrm{H} 7$ are rejected. This gives rise to the meaning that good information on social media does not necessarily make tourists believe, as well as a good destination image does not necessarily make tourists believe in a destination. However, experience has a significant effect on trust, so H6 is accepted. The influence of social media marketing and destination image on trust obtained this insignificant result means that Hypotheses 8 and 10 are automatically rejected based on the examination method. On the other hand, the direct effect of experience on the intention to revisit without using trust is at a coefficient of 0.447 which is significant. The effect of experience on the intention to revisit using trust is at a coefficient of 0.38 which is significant while the effect of experience on trust is at a coefficient of 0.33 which is significant while trust has a significant effect of 0.18 on the intention to revisit. Therefore, based on the examination method, the role of trust in mediating experience on revisit intentions is partial mediation.

\section{Discussion}

Tourists see information that is spread on social media to reduce the risks contained in tourist destinations (Sano, 2014), in this case stating that customers tend to feel risk in services rather than with products because many things cannot be understood. Kim and Ritchie (2013) stated in their research that stress levels affect tourists to seek travel experiences despite cultural differences. This study also found that the friendliness of the local community is one of the keys to sustainable tourism because the friendliness of the local community can make tourists feel at home and want to come back someday. Destination image has a significant effect on revisit intentions, therefore it is necessary to strengthen the image attributes that have been described in Beerli and Martin's (2004) research. trust has a significant effect on the intention to revisit. This indicates that the higher the confidence of tourists, the more tourists want to come back. At this time, the Covid-19 pandemic that hit the world also had an impact on Bali. Tourists who come only from domestic tourists plus strict health protocols further worsen tourism in Bali, which is usually always crowded with tourists. Therefore, high trust is needed for tourists so that tourists want to come back to Bali. Based on the results of hypothesis testing, it shows that social media marketing has a positive but not significant effect on trust. This indicates that although the information is of high quality, it does not necessarily make tourists believe in the products offered. This indicates that tourist travel in Bali is still at risk because the development of Covid-19 is still changing and not stable

Based on the results of hypothesis testing, it shows that social media marketing has a positive but not significant effect on trust. This indicates that although the information is of high quality, it does not necessarily make tourists believe in the products offered, besides the need for continuous updates, especially on media that often market Bali so that the information obtained is always new, especially the development of the COVID-19 pandemic in Bali. Based on the results of hypothesis testing, it shows that experience has a positive and significant effect on trust. This indicates that the better the experience you get while on vacation in Bali, the more trust you can get. The results of this study strengthen the research of Hao et al., (2015) who found that experience had a significant effect on trust. The same result was also found by Ardyan et al. (2016) who found that experience had a significant effect on trust. Based on hypothesis testing, it shows that the image of the destination has a positive but not significant effect. This indicates that the better the image of the destination, it does not necessarily make tourists believe in the tourist destination. The results of this study contradict the research of Endah et al., (2017) which found that the image of a destination has a significant effect on trust. The results of this study also contradict the research of Lien et al., (2016) who found that the image of the destination has a significant effect on trust

\section{Theorical implication}

Based on the data analysis and research results described above, the implications of this research are theoretical implications and practical implications. In theoretical implications, the results of this study contribute to the development of knowledge, insights and references for future researchers. This study contains the development of a model consisting of social media marketing, experience, destination image, trust and revisit intention. Social media marketing has an important role to increase the intention to revisit. Information contained in social media is an important issue in this study. The expected information is quality information consisting of relevance, timeliness, completeness, interestingness, value add and perceived risk. However, social media marketing has no significant effect on trust. This indicates that there are social media users spreading untrue information such as trolls (Mkono \& Tribe, 2016). Experience has a significant effect on the intention to revisit. The motivation of tourists to make a tourist visit is to get new experiences, vacation with family and escape from the routine of work. However, it is the friendliness of the local community that will make these tourists come back. This study also found that experience had a significant effect on trust. Experience during the trip is important as feeling inspired and enthusiastic during the trip can also form trust so that it can increase the intention to come back.

The image of the destination has a significant effect on the intention to revisit. This indicates that a good destination image can increase the intention to revisit for tourists. Another theoretical finding is that the destination image has no significant effect on trust. This indicates that a good destination image does not necessarily provide confidence for tourists, therefore more precise measurements are needed to measure the image of the destination. (Madden et al., 2016). 
Trust has a significant effect on the intention to revisit. In this case, trust is very important because it involves health protocols that are very important to do during the Covid-19 pandemic, such as the use of masks and the availability of hand sanitizers. The higher the trust it will have an impact on the intention to revisit

\section{Practical implication}

An important aspect of this research is the information contained in social media because information is part of the pull factor for the formation of a person's motivation to carry out tourism activities (Madden et al., 2016). Therefore, positive communication must be established between tourism actors and tourists. Positive communication can create benefits for tourist destinations, among others, tourists will tell interesting experiences to others so that they can attract potential tourists (Abubakar \& Ilkan, 2015). Good communication can also reduce miscommunication between tourism actors and tourists so that it can increase the intention of returning tourists. Destination image is an important antecedent for revisit intention. It is important to build a strong image and promote it through good marketing activities. Meanwhile the image of the destination is widely recognized by something strong in the tourism industry and can be used as an advantage in competitive competition (Foroudi et al., 2018). Therefore, it is necessary to maintain a good image in front of tourists because it can influence tourist decisions. Trust during the Covid-19 pandemic is very important. Therefore, community discipline in the use of masks, the availability of hand sanitizers and various other health protocols is very important, especially Bali, which has a very good image. Because a tourist destination is a place that is programmed to please its tourists but will not succeed if the reputation of the destination is bad and has an impact on trust in the destination. (Artigas et al., 2017). In the current new normal, it can be used as an important lesson for Bali tourism actors on how to adapt to change. Therefore, planning and rearranging the right business strategy to survive with the use and development of information technology today. The Covid-19 vaccine is very important to help create herd immunity. Therefore, the spread of the Covid-19 vaccine must be maximized in order to create herd immunity in the community. In addition, the Covid-19 vaccine can also help the body's immunity against Covid-19.

\section{Limitations and future research}

Like many other studies, this study also has limitations. The limitations of this study are that this study still uses domestic tourists due to differences in health protocols in various countries. This study only uses 125 respondents which is the minimum number. Besides that, retrieval of respondent information from the google form is an obstacle if there are respondents who do not understand the contents of the google form.

Future research is expected to cover the limitations of this study such as making comparisons between domestic tourists and international tourists, developing other models to increase revisit intentions such as motivation, self-congruity and push and pull factors. Cultural elements can also be added for future research. Destination image research to deal with Covid-19 also needs to be done.

\section{References}

Abubakar, A. M. (2016). Does eWOM influence destination trust and travel intention: a medical tourism perspective. Economic research-Ekonomska istraživanja, 29(1), 598-611.

Abubakar, A. M., \& Ilkan, M. (2016). Impact of online WOM on destination trust and intention to travel: A medical tourism perspective. Journal of Destination Marketing \& Management, 5(3), 192-201.

Abubakar, A. M., Ilkan, M., Al-Tal, R. M., \& Eluwole, K. K. (2017). eWOM, revisit intention, destination trust and gender. Journal of Hospitality and Tourism Management, 31, 220-227.

Ali, F., Ryu, K., \& Hussain, K. (2016). Influence of experiences on memories, satisfaction and behavioral intentions: A study of creative tourism. Journal of Travel \& Tourism Marketing, 33(1), 85-100.

Alhaddad, A. (2015). A structural model of the relationships between brand image, brand trust and brand loyalty. International Journal of Management Research and Reviews, 5(3), 137.

Amaro, S., Duarte, P., \& Henriques, C. (2016). Travelers' use of social media: A clustering approach. Annals of Tourism Research, 59, 1-15.

Ardyan, E., Kurnianingsih, H., Rahmawan, G., Wibisono, U., \& Winata, W. (2016). Enhancing brand experience along with emotional attachment towards trust and brand loyalty. Jurnal Manajemen dan Kewirausahaan (Journal of Management and Entrepreneurship), 18(1), 33-44.

Artigas, E. M., Yrigoyen, C. C., Moraga, E. T., \& Villalón, C. B. (2017). Determinants of trust towards tourist destinations. Journal of Destination Marketing \& Management, 6(4), 327-334.

Baloglu, S., \& McCleary, K. W. (1999). A model of destination image formation. Annals of tourism research, 26(4), 868897.

Başer, İ., Cintamür, İ., \& Arslan, F. (2015). Examining the effect of brand experience on consumer satisfaction, brand trust and brand loyalty. Marmara Üniversitesi İktisadi ve İdari Bilimler Dergisi, 37(2), 101-128.

Beerli, A., \& Martin, J. D. (2004). Factors influencing destination image. Annals of tourism research, 31(3), 657-681.

Calefato, F., Lanubile, F., \& Novielli, N. (2015). The role of social media in affective trust building in customer-supplier relationships. Electronic Commerce Research, 15(4), 453-482. 
Chandralal, L., \& Valenzuela, F. R. (2013). Exploring memorable tourism experiences: Antecedents and behavioural outcomes. Journal of Economics, Business and Management, 1(2), 177-181.

Chandralal, L., \& Valenzuela, F. R. (2015). Memorable Tourism Experiences; Scale Development.

Chen, C. F., \& Chen, F. S. (2010). Experience quality, perceived value, satisfaction and behavioral intentions for heritage tourists. Tourism management, 31(1), 29-35.

Chen, C. F., \& Phou, S. (2013). A closer look at destination: Image, personality, relationship and loyalty. Tourism management, 36, 269-278.

Coudounaris, D. N., \& Sthapit, E. (2017). Antecedents of memorable tourism experience related to behavioral intentions. Psychology \& Marketing, 34(12), 1084-1093.

Crossley, É. (2020). Ecological grief generates desire for environmental healing in tourism after COVID-19. Tourism Geographies, 22(3), 536-546.

DeLone, W. H., \& McLean, E. R. (2003). The DeLone and McLean model of information systems success: a ten-year update. Journal of management information systems, 19(4), 9-30.

Deng, Q., \& Li, M. (2014). A model of event-destination image transfer. Journal of Travel Research, 53(1), 69-82.

Endah, P. E., Umar, N., Suharyono, S., \& Andriani, K. (2017). Study on destination image, satisfaction, trust and behavioral intention. Russian Journal of Agricultural and Socio-Economic Sciences, 61(1).

Filieri, R., Alguezaui, S., \& McLeay, F. (2015). Why do travelers trust TripAdvisor? Antecedents of trust towards consumergenerated media and its influence on recommendation adoption and word of mouth. Tourism management, 51, 174-185.

Foroudi, P., Akarsu, T. N., Ageeva, E., Foroudi, M. M., Dennis, C., \& Melewar, T. C. (2018). Promising the dream: Changing destination image of London through the effect of website place. Journal of Business Research, 83, 97-110.

Jiang, Y., \& Ritchie, B. W. (2017). Disaster collaboration in tourism: Motives, impediments and success factors. Journal of Hospitality and Tourism Management, 31, 70-82.

Hao Suan Samuel, L., Balaji, M. S., \& Kok Wei, K. (2015). An investigation of online shopping experience on trust and behavioral intentions. Journal of Internet Commerce, 14(2), 233-254.

Hassan, S. B., \& Soliman, M. (2021). COVID-19 and repeat visitation: Assessing the role of destination social responsibility, destination reputation, holidaymakers' trust and fear arousal. Journal of Destination Marketing \& Management, 19 , 100495.

Hajli, N., Lin, X., Featherman, M., \& Wang, Y. (2014). Social word of mouth: How trust develops in the market. International Journal of Market Research, 56(5), 673-689.

Hajli, M. N. (2014). A study of the impact of social media on consumers. International journal of market research, 56(3), 387-404.

Hajli, N., Sims, J., Zadeh, A. H., \& Richard, M. O. (2017). A social commerce investigation of the role of trust in a social networking site on purchase intentions. Journal of Business Research, 71, 133-141.

Huang, C. C. (2017). The impacts of brand experiences on brand loyalty: mediators of brand love and trust. Management Decision.

Helble, M., \& Fink, A. (2020). Reviving Tourism amid the COVID-19 Pandemic1.

Kim, S., \& Park, H. (2013). Effects of various characteristics of social commerce (s-commerce) on consumers' trust and trust performance. International Journal of Information Management, 33(2), 318-332.

Kim, A. J., \& Ko, E. (2010). Impacts of luxury fashion brand's social media marketing on customer relationship and purchase intention. Journal of Global Fashion Marketing, 1(3), 164-171.

Kim, A. J., \& Ko, E. (2012). Do social media marketing activities enhance customer equity? An empirical study of luxury fashion brand. Journal of Business research, 65(10), 1480-1486.

Kim, J. H., Ritchie, J. B., \& McCormick, B. (2012). Development of a scale to measure memorable tourism experiences. Journal of Travel research, 51(1), 12-25.

Kim, J. H. (2014). The antecedents of memorable tourism experiences: The development of a scale to measure the destination attributes associated with memorable experiences. Tourism management, 44, 34-45.

Kim, J. H., \& Ritchie, J. B. (2014). Cross-cultural validation of a memorable tourism experience scale (MTES). Journal of Travel Research, 53(3), 323-335.

Kim, S. E., Lee, K. Y., Shin, S. I., \& Yang, S. B. (2017). Effects of tourism information quality in social media on destination image formation: The case of Sina Weibo. Information \& management, 54(6), 687-702.

Kim, J. H. (2018). The impact of memorable tourism experiences on loyalty behaviors: The mediating effects of destination image and satisfaction. Journal of Travel Research, 57(7), 856-870.

Laroche, M., Habibi, M. R., \& Richard, M. O. (2013). To be or not to be in social media: How brand loyalty is affected by social media?. International journal of information management, 33(1), 76-82.

Li, H. O. Y., Bailey, A., Huynh, D., \& Chan, J. (2020). YouTube as a source of information on COVID-19: a pandemic of misinformation?. BMJ global health, 5(5), e002604.

Lee, Y. W., Strong, D. M., Kahn, B. K., \& Wang, R. Y. (2002). AIMQ: a methodology for information quality assessment. Information \& management, 40(2), 133-146.

Lien, C. H., Wen, M. J., Huang, L. C., \& Wu, K. L. (2015). Online hotel booking: The effects of brand image, price, trust and value on purchase intentions. Asia Pacific Management Review, 20(4), 210-218.

Lin, J., Yan, Y., \& Chen, S. (2017). Understanding the impact of social commerce website technical features on repurchase intention: a Chinese guanxi perspective. Journal of Electronic Commerce Research, 18(3), 225. 
Mahika, E. C. (2011). Current trends in tourist motivation. Cactus Tourism Journal, 2(2), 15-24.

Mkono, M., \& Tribe, J. (2017). Beyond reviewing: Uncovering the multiple roles of tourism social media users. Journal of travel research, 56(3), 287-298.

Ramseook-Munhurrun, P., Seebaluck, V. N., \& Naidoo, P. (2015). Examining the structural relationships of destination image, perceived value, tourist satisfaction and loyalty: case of Mauritius. Procedia-Social and Behavioral Sciences, 175 , 252-259.

Roy, M. C., Dewit, O., \& Aubert, B. A. (2001). The impact of interface usability on trust in web retailers. Internet research.

Sahin, A., Zehir, C., \& Kitapçı, H. (2011). The effects of brand experiences, trust and satisfaction on building brand loyalty; an empirical research on global brands. Procedia-Social and Behavioral Sciences, 24, 1288-1301.

Sano, K. (2014). Do social media marketing activities enhance customer satisfaction, promote positive WOM and affect behavior intention?: an investigation into the effects of social media on the tourism industry. 同志社商学, 66(3), 491-515.

Shrivastava, P. (2016). Effect of co-creation on customer experience, trust and brand loyalty. International Journal of Sales \& Marketing Management Research and Development (IJSMMRD), 6(6), 1-14.

Sigala, M. (2020). Tourism and COVID-19: Impacts and implications for advancing and resetting industry and research. Journal of business research, 117, 312-321.

Stylos, N., Vassiliadis, C. A., Bellou, V., \& Andronikidis, A. (2016). Destination images, holistic images and personal normative beliefs: Predictors of intention to revisit a destination. Tourism Management, 53, 40-60.

Stylos, N., Bellou, V., Andronikidis, A., \& Vassiliadis, C. A. (2017). Linking the dots among destination images, place attachment, and revisit intentions: A study among British and Russian tourists. Tourism Management, 60, 15-29.

Stylos, N., \& Bellou, V. (2019). Investigating tourists' revisit proxies: The key role of destination loyalty and its dimensions. Journal of Travel Research, 58(7), 1123-1145.

Song, H., Wang, J., \& Han, H. (2019). Effect of image, satisfaction, trust, love, and respect on loyalty formation for namebrand coffee shops. International Journal of Hospitality Management, 79, 50-59.

Souiden, N., Ladhari, R., \& Chiadmi, N. E. (2017). Destination personality and destination image. Journal of Hospitality and Tourism Management, 32, 54-70.

Tasci, A. D., \& Ko, Y. J. (2017). Travel needs revisited. Journal of Vacation Marketing, 23(1), 20-36.

Tatar, Ş. B., \& Eren-Erdoğmuş, İ. (2016). The effect of social media marketing on brand trust and brand loyalty for hotels. Information Technology \& Tourism, 16(3), 249-263.

Tosun, C., Dedeoğlu, B. B., \& Fyall, A. (2015). Destination service quality, affective image and revisit intention: The moderating role of past experience. Journal of Destination Marketing \& Management, 4(4), 222-234.

World Health Organization. (2020). Operational considerations for COVID-19 management in the accommodation sector: interim guidance, 31 March 2020 (No. WHO/2019-nCoV/Hotels/2020.1). World Health Organization.

UNWTO. 2020. UNWTO World Tourism Barometer Vol. 18, Issue 2, May 2020. Madrid, Spain: UNWTO

Wang, Y. H., \& Lee, C. C. (2016). Does winning an award matter to brand trust and purchase intention? Evidence from franklin templeton investments. Journal of Business \& Economic Policy, 3(1), 75-81.

Wang, C., Pan, R., Wan, X., Tan, Y., Xu, L., Ho, C. S., \& Ho, R. C. (2020). Immediate psychological responses and associated factors during the initial stage of the 2019 coronavirus disease (COVID-19) epidemic among the general population in China. International journal of environmental research and public health, 17(5), 1729.

Yeh, S. S. (2021). Tourism recovery strategy against COVID-19 pandemic. Tourism Recreation Research, 46(2), $188-194$.

Zhang, H., Fu, X., Cai, L. A., \& Lu, L. (2014). Destination image and tourist loyalty: A meta-analysis. Tourism management, 40, 213-223.

Zhang, H., Wu, Y., \& Buhalis, D. (2018). A model of perceived image, memorable tourism experiences and revisit intention. Journal of destination marketing \& management, 8, 326-336.

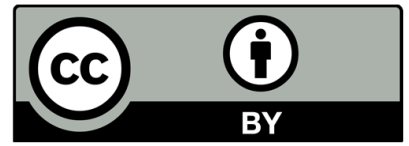

(C) 2022 by the authors; licensee Growing Science, Canada. This is an open access article distributed under the terms and conditions of the Creative Commons Attribution (CC-BY) license (http://creativecommons.org/licenses/by/4.0/). 